\title{
Biologically effective doses of ambient solar-UV radiation in Indonesia and Japan
}

Nobuo Munakata ${ }^{1}$, Santoso Cornain ${ }^{2}$, Ketut Mulyadi ${ }^{3}$, Masamitsu Ichihashi ${ }^{4}$, Joedo Prihartono ${ }^{5}$, Yoshiyuki Ohno ${ }^{6}$, Mochtar Hamzah ${ }^{7}$, Mpu Kanoko ${ }^{2}$, Evert Poetiray ${ }^{8}$, Setyawati Budiningsih", Achmad Tjarta ${ }^{2}$, Masato Ueda Herman Cipto ${ }^{7}$, Arman Mukhtar ${ }^{8}$

\begin{abstract}
Abstrak
Dosis yang menggambarkan efektifitas biologik dari radiasi sinar ultraviolet dari matahari dalam kondisi sehari-hari ditetapkan menggunakan dosimeter spora, baik di Indonesia maupun di Jepang. Nilai dosis maksimum pada tengah hari yang diukur di Denpasar adalah 0,6 DIS/menit (dosis inaktivasi spora per menit) yang kira-kira dua kali dosis yang diukur di Tokyo pada hari-hari cerah pada ketinggian matahari yang mirip. Sampel dosimeter ditutup dengan dua jenis lembaran polietilen berwarna biru agar memungkinkan pengukuran dosis kumulatif tiap hari dan tiap bulan. Dosis yang diukur tiap bulan menunjukkan perbedaan menyolok dari pola perubahan menurut musim baik di Indonesia maupun di Jepang. Nilai yang diperkirakan dari DIS untuk sepanjang tahun dari September 1998 adalah masing-masing 10.000, 29.0-00 dan 53.000 di Tokyo, Jakarta dan Denpasar.
\end{abstract}

\begin{abstract}
Biologically effective doses of ambient solar-UV radiation were determined using spore dosimeters both in Indonesia and in Japan. The maximum noontime dose rates determined at Denpasar were $0.6 \mathrm{SID} /$ min (spore inactivation dose per minute), that was about twice as high as obtained in Tokyo on clear days at a similar solar altitude. Samples were covered with two types of blue polyethylene sheet to allow the measurement of cumulative daily and monthly doses. Monthly doses exhibited striking differences in the pattern of seasonal changes in Indonesia and Japan. Estimated values of SiD for a whole year from September 1998 were 10,000, 29,000 and 53,000 at Tokyo, Jakarta and Denpasar, respectively.
\end{abstract}

Keywords : solar ultraviolet, spore dosimeter, biological method

Various types of evidence indicate that the exposure to solar-UV radiation is the major to solar-UV radiation is the major cause for skin carcinogenesis. Molecular studies of p53 and patched gene mutations

\footnotetext{
'Radiobiology Division, National Cancer Center Research Institute, Tokyo 104-0045, Japan

2 Department of Anatomic Pathology, Faculty of Medicine, University of Indonesia, Jakarta 10430, Indonesia

${ }^{3}$ Department of Anatomic Pathology, Faculty of Medicine, Udayana University, Denpasar 80119, Indonesia

4 Department of Dermatology, Kobe University School of Medicine, Kobe 650-0017, Japan

5 Department of Community Medicine, Faculty of Medicine, University of Indonesia, Jakarta 10320, Indonesia

${ }^{6}$ Department of Preventive Medicine, Nagoya University School of Medicine, Nagoya 466-8550, Japan

7 Department of Dermatology, Faculty of Medicine, University of Indonesia, Jakarta 10430, Indonesia

${ }^{\&}$ Department of Surgery, Faculty of Medicine, University of Indonesia, Jakarta 10430, Indonesia
}

substantiated that the majority of the cancer cells carries signature mutations of UV exposure from the sun. ${ }^{1,2}$ Therefore, the skin cancer epidemiology needs to be based on the quantification of ambient UV radiation. However, the studies correlating the skin cancer incidence and UV intensity have been focused mainly on Caucasian populations migrating from low to high intensity environtment. ${ }^{3}$

It is generally assumed that indigenous people in Asia are protected from various levels of UV radiation by skin pigmentations. Though solid data for skin cancer incidence are not available, several reports indicate higher incidence in Indonesia than in Japan as referenced in the Progress Report on Japan-Indonesia Joint Study. One of the purposes of this work is to see what portion of this difference in the skin cancer incidence could be explained by the difference in the environmental UV intensity between Japan and Indonesia. 
There are several ways to approach the measurement of ambient UV radiation. Comprehensive physical description could be provided by spectroradiomenters. However, the instruments are bulky and expensive, and require careful and perpetual handling, maintenance and calibration to produce accurate and consistent data. In Japan, the Metereological Agency installed four Brewer-type spectrometers and the hourly measurements have been carried out since $19900^{4}$ As we know, a similar monitoring system has not been materialized in Indonesia.

There are several devices that measure the UVB irradiance, i.e. the integral of irradiance in the range of 280 to $320 \mathrm{~nm}$ (or 290 to $315 \mathrm{~nm}$ ). Difficulties in establishing the accuracy and standardization are also the problem with these broadband meters. In addition, all physical measurements require a method of conversions to biclogically effective doses. There is satisfactory way for this conversion in the case with broadband measurements.

Biodosimetry of solar-UV radiation has been developec and empluyed to overcome these problems. In this case, the observed effect, such as cellular lethality and mutagenesis, represents the final outcome of incident radiation, naturally integrating the effects of all the pertinent wavelengths. Major causes of cellular lethality are DNA photoproducts induced by radiation. Thus, the assay of lethality could be considered to be the measurements of the yields of DNA photoproducts. However, in practice, the usable biological systems are limited because of the adversities encountered outside the laboratory. In any fields work (or working by mail), it is important that the materials can be dried to ease the handling. The only types of microbial cells that could be safely dried alive for a long time are bacterial spores. One prototype biodosimeter is the spore dosymetry using UV-hypersensitive spores of Bacillus subtilis dried on a membrane. ${ }^{5}$

The strain originated from the genetic analyses of UV-resistance of B. subtilis spores carried out since $1960 \mathrm{~s}^{6}$ The major photoproducts produced in spore DNA are "spore photoproducts (5-thyminyl-5,6dihydrothymine)". They are repaired by two repair mechanisms, one is nucleotide excision repair, which also functions upon cyclobutane pyrimidine dimers and 6,4-photoproducts produced in vegetative cells and the other is spore-specific repair. Mutants deficient in either one of the two mechanisms still exhibit levels of UV resistance not much different from the wild-type ones. However, when two mutations are combined to produce double mutants, the resultant spores exhibit the extreme UV sensitivity, while retaining all the resistance to various physical and chemical assaults. It is also notable that these spores exhibit strictly exponential inactivation, in contrast to the wild-type spores exhibiting a moderate shoulder in survival curves. ${ }^{7}$

These features of mutant spores, hyper-sensitivity and straight lethal kinetics are exploited to develop the spore dosimetry. The characterization culminated in the first experimental validation of the concept of the solar effective spectrum, originally proposed by Setlow (1974) ${ }^{8}$ Under the assumption of wavelength independence, the spectral irradiance and the action spectra can be multiplied to produce the effectiveness spectrum. The convolution of the spectrum through whole wavelength range provides the estimate of biological effect and can be compared with the real experimental values.

In this work, the system was further adapted to be used for direct comparisons at several localities in Indonesia and Japan with regard to dose rates, cumulative daily and monthly doses of solar radiation.

\section{MATERIALS AND METHODS}

Samples of spore dosimetry have been described before $^{5,10,11}$ and a brief description is given here. Suspension of the spores of repair-deficient strain TKJ6312 ( $u v r \quad s p l$ ) was mixed with molten lowmelting agarose $(0.6 \%$. SeaPlaque) and blue dextran $(0.04 \%)$. Four $5 \mu \mathrm{l}$ spots each carrying about $10^{6}$ spores are made on membrane filter (pore size $=0.1$ $\mu \mathrm{m}, \mathrm{A} 0110 \mathrm{~A} 025$, Advantec) under a weak vacuum. After drying, the filter with four-spore spots is snapped in a slide mount with a plastic back. Two spots were covered with pieces of white and black paper serving as unexposed controls.

Samples for dose rate measurements were exposed without covering materials. Those for longer exposure required filter sheets to reduce the dose and to protect samples from rain. Two types of blue polyethylene sheet with different thickness were used: one (BPS04) with a thickness of $0.04 \mathrm{~mm}$ and the other (BPS07) with a thickness of $0.07 \mathrm{~mm}$. The optical properties of these two types of filter sheet have been describes. "I The BPS04 and BPS07 sheet reduces the effective dose to $48 \%$ and $7.1 \%$, respectively. For daily total 
determination, the reduction of 29.1 times was affected by a combination of each one sheet of BPSO4 and BPS07 with or without the addiction of one or two sheets of BPS04 affected the reduction of 196, 408 and 848 times, respectively.

The exposure was perforimed by placing samples horizontally on unshaded surface. The sites were on the roof of National Cancer Center in Tokyo $\left(35.68^{\circ}\right.$ $\mathrm{N}, 139.76^{\circ} \mathrm{E}$ ), University of Indonesia in Jakarta $\left(6.18^{\circ} \mathrm{S}, 106.83^{\circ} \mathrm{E}\right)$ and Udayana University in Denpasar $\left(8.58^{\circ} \mathrm{S}, 115.17^{\circ} \mathrm{E}\right)$. Comparative monthly measurements are ongoing at five sites in Japan and two sites in Europe since January 1999 and the results will be presented in future reports. In the case of dose rate measurement at Denpasar, the rate $\left(\mathrm{W} / \mathrm{m}^{2}\right)$ and cumulative UVB irradiance $\left(\mathrm{J} / \mathrm{m}^{2}\right)$ were also determined with a portable UV monitor (MS-211-I, Eiko Seiki, Tokyo).

After the exposure, the colony-forming survival was determined and used to obtain the spore inactivation dose $(\mathrm{SID})$ from a relationship. SID $=-\mathrm{In}(\mathrm{Ne} / \mathrm{Nc})$, where NE and NC stand for the number of colonyforming units obtained from exposed and control samples, respectively. Since the spores are dormant and exhibit no metabolic activity including DNA repair, these values of SID represent the amounts of cumulated DNA photoproducts in the spores. Total recovery of unexposed samples was confirmed from the fact that the deviation of the numbers of colony formers was within the allowance of microbiological manipulation (less than $\pm 15 \%$ ).

\section{RESULTS}

\section{Noontime dose rates at Denpasar}

On August 2, 1997 and September 3, 1998, the noontine dose rates were determined on the roof of Udayana University where following daily and monthly exposures have also been performed. Each sample was exposed for 10 or 15 minutes between 11.00 and 13.00 . By dividing the resulting value of SID by the length of exposure, the dose rate was obtained in a unit of SID per minute (SID/min). As shown in Figure 1, the values fluctuated between 0.38 and 0.60 . As expected, these values were quite high in comparison to previous data at Tokyo, where the highest value recorded was $0.42,{ }^{12}$ but not extraordinary high in comparison to summer dose in southern parts of Japan as seen in the DISCUSSION.

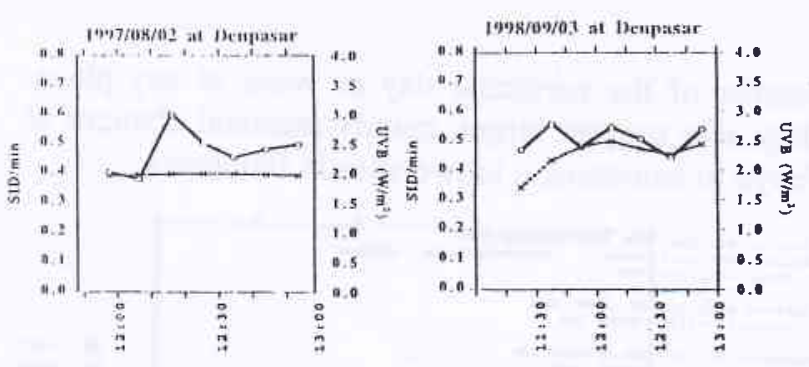

Figure 1. Noontime UVB dose rates measured for $10-15$ minutes at Udayana University, Denpasar

\section{Synchronous weekly measurements at Tokyo,} Jakarta and Denpasar

One of biologically relevant modalities of solar-UV dosimetry is the cumulative daily dose from sunrise to sunset. In order to determine the daily dose with spore dosimetry in the original method, however, it is necessary to change samples frequently, because of the limitation for the maximum dose each sample can determine. Since the initial number of the spores in each spot is about $10^{6}$, no viable spores are left when the survival declines below $10^{-6}$ corresponding to about 12 SID. For example, the maximum dose rate at Denpasar in the above irradiation was about 0.6 , $\mathrm{SID} / \mathrm{min}$ at noontime, therefore, it would have exceeded the measurable range after 20 minutes. Though it is possible to perform total daily measurements occasionally, it demands too much labor and resources and not practical for monitoring and comparisons. A combination of two sheets of blue polyethylene filter, BPS04 and BPS07, are found useful for the reduction of the irradiance.

The next question was how often and when these daily comparisons should be done. For this, we have adapted the protocol used for the monitoring of schoolchildren and aduits in Japan, ${ }^{11}$ choosing one week in each-three months.

We have started the comparisons since August 1997 at Jakarta and Tokyo, and since February 1998 at Denpasar. The results of daily doses for seven consecutive days are shown in Figure 2. As it stands now, there are six weeks to compare between Jakarta and Tokyo and four weeks to compare among the three sites, including Denpasar.

The maximum weekly doses at Tokyo, Jakarta and Denpasar were 298, 825 and 924 SID, respectively, while the minimum were 1,10 and 18 SID. The results indicate large variabilities, mostly due to the 
weather of the particular day or week at any place. They also suggest larger, mainly seasonal changes at Tokyo in comparisoñ to two sites in Indonesia.

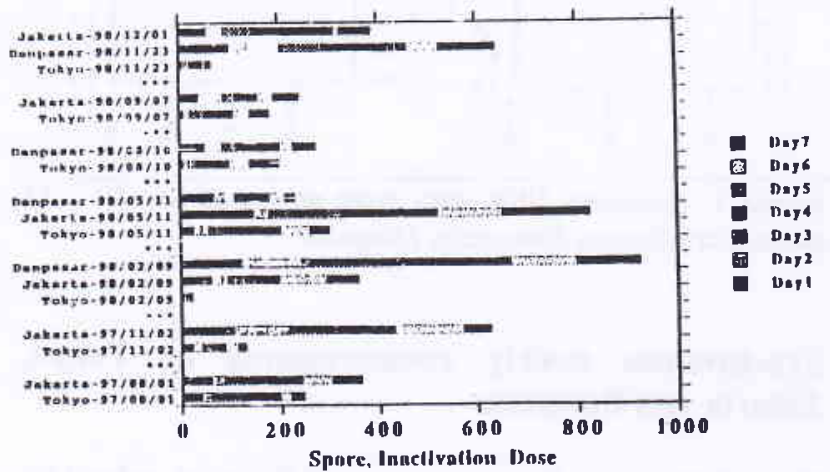

Figure 2. Daily UVB dose measured during 1 week every 3 months synchronously at Tokyo, Jakarta ana Denpasar

\section{Continual measurement of monthly doses at Tokyo, Jakarta and Denpasar}

Though the previous results provide some information on the daily and weekly doses of ambient UVB, these data are inevitably affected by weather conditions of particular week of the measurements and it can not be ascertained that they are representative or exceptional. On the other hand, it is prohibitable to carry out continual daily measurements at places other than Tokyo where the production and assays of the spore dosimeters have been performed. To circumvent this, it was thought that further reduction of the irradiance with additional filters might allow the extension of the measurement period. Thus, as the initial trial, two samples, one covered with four sheets of filters, two BPS04 and two BPS07, were used. From experience of one year measurements, these two combinations are appropriate in all months in Indonesia, whereas at Tokyo in low incident months. (from October to April), the former one needs to be replaced with two sheets of BPS07 only.

The initial exposure from September 1998 and as it stands now, a whole year was covered as shown in Figure 3 . There are several mishaps that prevented the analysis. The most crucial one occurred in January 1998 at Jakarta, when the samples were totally spoiled by heavy rainfall. This alerted us to make tighter seals over the wrapping of the filter sheets and after this month, all samples apparently survived the rain. On the other hand, the January samples at Denpasar disappeared with unknown reason. Also, due to the delay in mail, the February samples at Denpasar were exposed only the last 10 days and the value was multiplied by 2.8 to provide the monthly estimate.

At Tokyo, characteristic seasonal changes are observed, a rapid decline from September (1,162 SID) to October (389 SID) and a rapid incidence from March (122 SD) to April (1,058 SID). The bottom value (102 SID) was in February, while the peak value (102 SID) was in February, while the peak value $(2,214 \mathrm{SD})$ was in July. The reason for a drop in June is likely is likely to be rainy weather in this month.

At Jakarta, the monthly doses were similar from September to December and declined steeply to the minimum value (718 SD) in February (the data in January are missing). After this, a sharp increase to the maximum value $(4,210$ SID) in April was followed by a small decreased to July. Out of 11 months, seven stayed within a relatively small, interval between 2,400 and 3,100 SID.

At Denpasar, the monthly doses were always higher than Jakarta and Tokyo. From September to March, they exhibited a parallel changes to those seen at Jakarta, relatively stable months (September to December) were followed by a decline in February (the January data are missing) and a recovery in March. Interestingly, here the minimum value $(2,927$ SID) in February was followed by the maximum value $(6,229 \mathrm{SID})$ in March. After this, more or less stable months were followed.

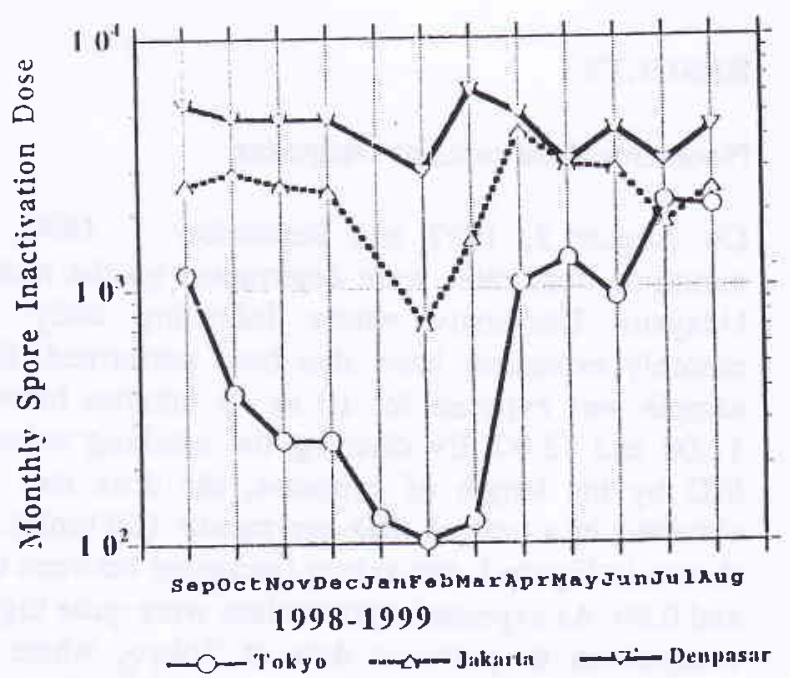

Figure 3. Monthly UVB dose during September 1998 to August 1999, measured synchronously at Tokyo, Jakarta 


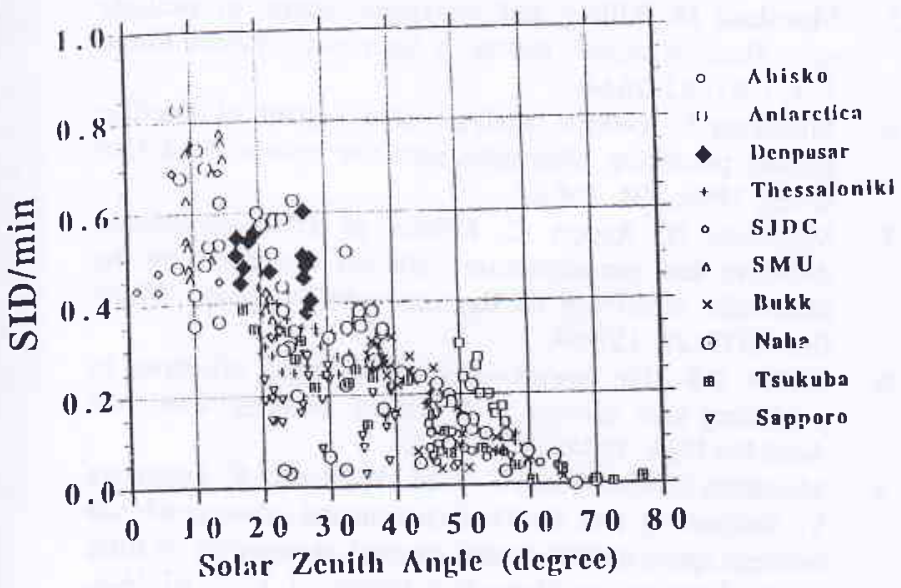

Figure 4. Distribution of UVB dose rates according to Solar Zenith Angle at Denpasar, as compared to various places at the globe

\section{DISCUSSION}

The radiation sensitivity of biological organism is the intrinsic characteristics of the biological system. The biologically effective doses can be directly determined by the careful quantification of the effect. In contracts, physical instruments need to be constantly calibrated and standardized, which is very difficult to attain with regard to UV radiation. From these aspects, biodosimetry is advantageous in allowing direct comparisons among the distant locations. It is especially important that present results confirmed the adaptability of the spore dosimetry in tropical environment under intense heat. Previously, spore dosimetry was employed to determine noontime dose rates and daily doses in the Antarctica ${ }^{13}$ and Abisko in Northern Sweeden ${ }^{14}$. We could conclude that this system could be used anywhere on the earth from polar or tropical regions.

The dose rates of ambient UV are dependent primarily on solar zenith angle, cloudiness, ozone concentration and air opacity. To place the noontime dose rate measurements in a global perspective, the values obtained at Denpasar were plotted against solar zenith angles in Figure 4. There are several comparable data obtained at Naha in Okinawa Island in southernmost Japan. The highest value (SID/min) was observed at Naha, when the solar zenith angle was $7.9^{\circ}$. The values at Denpasar are within a line which connects this value and zero at $70^{\circ}$. However, the dose rate measurements under high solar altitudes have not been carried out systematically and it would be highly desirable extend these measurements in Indonesia.
In addition to the solar altitude, there are many confounding and contributing factors affecting the irradiance. Major ones are cloudiness, ozone concentration and air transparency, all of which are variable in complex ways. The daily and weekly measurements were particularly dependent on the weather. To perform quantitative comparisons a lot of measurements seem required, which is not possible under current circumstances.

The measurements of cumulative monthly doses become possible for the first time and we believe this is a major achievement. Except a few months with missing data, the results have demonstrated that the continuous monitoring of solar-UV radiation is possible with the spore dosimetry under variable and often harsh tropical environment such as burning heat and torrential rain. When we make up for the estimates of missing months (January 1998 at Jakarta and Denpasar) by the mean values of flanking months, we car provide the estimates doses for an entire year at the three sites; 10,000, 29,000 and $53,000 \mathrm{SID}$ at Tokyo, Jakarta and Denpasar, respectively. This means that there are less than 3 folds UV doses at Jakarta in comparison to those at Tokyo. These differences are particularly conspicuous throughout the late autumn and early spring months (from October to March) in Tokyo. In July 1999, the value of SID at Tokyo exceeded that at Jakarta, this was the only month when the dose in Indonesia was lower than in Japan.

There are significant differences (about 1.8 times) of UV doses at Jakarta and Denpasar. This differences also depend on the season that large differences in February and March are followed by small ones in April and May, and relatively constant ones through the other months. One contributing factor of the difference could be lower air-transparency due to urban air pellution in Jakarta. The climatic differences of cloudiness and precipitation might be also involved and at this point, we are not certain how much of the difference might be explained by the air opacity. It is worthwhile to extend the measurements to other sites in Indonesia as the multicenter project in order to analyze the causes for the variability of ambient UV doses.

\section{Acknowledgement}

We are grateful to the Deans of Faculty of Medicines, University of Indonesia and Udayana University, also the Heads of the Departments of Pathologies, for the 
arrangements of the UVB measurement at Jakarta and Denpasar.

This work has been supported by the grant No. 99042004 under Ministry of Education, Science, Sports and Culture, Government of Japan and partly supported by the Indonesian Cancer Foundation, the Jakarta International Cancer Conference Fund and the Terry Fox Foundation, Canada. The collaborative Study was initiated with Dean's approval No. 845/PT02.H4.FK/E/97 and technical support by the Director of Dr. Cipto Mangunkusumo National Central General Hospital.

\section{REFERENCES}

1. Ziegler A, Leffell D, Kunala S, Sharma H, Gailani M, Simon J, Halperin A, Baden H, Shapiro B, Bale A and Brash D. Mutation hotspots due to sunlight in the p53 gene of non-melanoma skin cancers. Proc. Natl Acad Sci USA, 1993; 90: 4216-20.

2. Bodak N, Queille S, Avril MF, Bouadjar B, Drougard C, Sarasin A and Daya-Grosjean L. High levels of patched gene mutations in basal-cell carcinomas from patients with xeroderma pigmentosum. Proc. Natl Acad Sci USA 1999; 96: 5117-22.

3. IARC Monographs on the Evaluation of Carcinogenesis Risks to Humans. Solar and Ultraviolet Radiation. IARC Lyon, 1992: 55.

4. Ito T. UVB observation network in the Japan meteorological agency, In: Shima A, Ichihashi M, Fujiwara Y, Takebe H, editors. Frontiers of Photobiology. Elsevier, Amsterdam, 1993; 515-8.
5. Munakata M. Killing and mutagenic action of sunlight upon Bacillus subtilis spores: a dosimetric system. Mutat Res, 1981; 82: 263-8.

6. Munakata N. Genetic analysis of a mutant of Bacillus subtilis producing ultraviolet sensitive spores. Mol Gen Genet, 1996; 104: 258-63.

7. Munakata N, Rupert C. Effects of DNA-polymerase detective and recombination deficient mutations on the ultraviolet sensitivity of Bacillus subtilis spores. Mutat Res, 1975; 27: 157-69.

8. Setlow RB. The wavelengths in surlight effective in producing skin cancer: a theoritical analysis. Proc Nat Acad Sci USA, 1974; 71: 336́3-6.

9. Munakata N. Moroboshi F, Hieda K, Suzuki K, Furusawa $\mathrm{Y}$, Shimura $\mathrm{H}$ and Ito $\mathrm{H}$. Experimental correspondence between spore dosimetry and spectral photometry of solar ultraviolet radiation. Photochem Photobiol, 1996; 63:74-8.

10. Munakata N. Biologically effective dose of solar ultraviolet radiation estimated by spore dosimetry in Tokyo since 1980. Photochem Photobiol, 1993; 58: 386-92.

11. Munakata $\mathrm{N}$, Ono $\mathrm{M}$ and Watanabe S. Monitoring of solar-UV exposure among schoolchildren in five Japanese cities using spore dosimeter and UV-coloring labels. Jpn J Cancer Res, 1998; 89: 235-45.

12. Munakata N. Continual increase in biologically effective dose of solar UV radiation determined by spore dosimetry from 1980 to 1993 in Tokyo. J Photochem Photobiol, 1995; 31: 63-8.

13. Munakata N. Makita K, Bolsee D, Gillotay D. Horneck G. Spore dosimetry of solar UV radiation: applications to monitoring of daily irradiance and personal exposure. Adv Space Res (in press).

14. Munakata N. Comparative measurements of solar UV radiation with spore dosimetry at three European and two Japanese sites. J Photochem Photobiol. B: Biol 1999; 53: 7-11. 